\title{
The Interpellator, The Body-archive, and The Spectral Observer: Uses of the Archives in Rithy Panh's S21 Trilogy
}

\author{
Eric Galmard
}

\begin{abstract}
The aim of this paper is to analyse the uses of the archives as deployed in three films by Rithy Panh: Bophana: A Cambodian Tragedy, S21: The Khmer Rouge Death Machine and Duch, Master of the Forges of Hell. Starting with the French intellectual debate about representations of the Shoah that fall in two opposite camps articulated around Jean-Luc Godard and Claude Lanzmann concerning the use of photographic and audiovisual archives to represent totalitarian mass killings, the intention is to show how Rithy Panh bypasses this polarisation in his films using the archives with three main functions: the interpellation-archive, the body-archive, and the spectral archive.
\end{abstract}

Keywords: mass killing; perpetrator; testimony; visual archive

In this paper I take a closer look at Rithy Panh's use of archives in three films: Bophana: a Cambodian Tragedy (1996), S21: The Khmer Rouge Death Machine (2003), and Duch, Master of the Forges of Hell (2012). The three films seem undoubtedly linked to form a trilogy about S21, the main torture and execution centre of the Khmer Rouge regime. Bophana does not initially focus exclusively on S21 but keeps returning to it; in this film, Rithy Panh finds his cinematographic approach to consider S21. On the other hand, S21 and Duch have two different kinds of documentary mise-en-scene, but fall under the same cinematographic approach to grapple with the place and the questions it raises.

To better distinguish the originality of Rithy Panh's approach to the use of archives, I begin with a detour and return (as Jean-Michel Frodon [2004a] suggested in an article in Cahiers du Cinema devoted to the film $S 21$ on its release) to the French intellectual context of a long polemic about representations of the Holocaust, one of the most well-known episodes of which coincided with the production of $S 21$. 
It is germane to this analysis because it is part of the intellectual world to which in a sense Rithy Panh belongs. It concerns the controversy that followed the opening of an exhibition in Paris titled "Memory of the Camps" and subtitled "Photographs of the Nazi Concentration and Extermination Camps", and was particularly centered around a text for the catalogue titled "Images In Spite of All," by the philosopher and art historian Georges DidiHuberman (2001). ${ }^{1}$ This text, the first chapter of which was titled "Four Pieces of Film Snatched from Hell", analyzed the "production context" (if one can use such terms) and the meanings that might be attributed to four photographs taken in August 1944 by members of the Auschwitz Sonderkommando (units of Jewish prisoners forced to work in the gas chambers) who photographed firstly an incineration pit and then some naked women outside who were about to be gassed.

Didi-Hubermann (2003) counters notions of the unimaginable and the unrepresentable associated with the Shoah (Hebrew term for the Holocaust) by framing the photos as an act of fundamental resistance against the Nazi policy of eliminating all traces of genocidal crime. According to DidiHubermann, while the images do not, of course tell "the whole truth", they do constitute a "representation nevertheless", "which imposes itself as the representation par excellence, the necessary representation of a particular moment in August 1944 at crematory number five at Auschwitz" (p. 55).

This text unleashed a backlash of vociferous attacks, most notably from the philosopher Gérard Wajcman (2001) in an article published in "Les Temps Modernes, the famous review founded by Jean-Paul Sartre. According to Wajcman, these photographs lied. They said nothing about the reality of genocide. Firstly because they showed only the "before and after" rather than the moment of extermination itself. Secondly, in a philosophical sense, because reality cannot be absorbed entirely into the visible, and thirdly, above all, because the Shoah, as a catastrophic event, constitutes a sort of aporia: a challenge to thought which resists any attempt at portrayal.

Behind Didi-Hubermann and Wajcman, the two adversaries, it is easy to recognize two great tutelary figures: Jean-Luc Godard and Claude Lanzmann (who directed the film of reference Shoah [1985]). Godard (1998) aligns himself with the belief in the salvationary capacity of the image, in spite of everything and despite all the historical conditions, to preserve a trace, to fight against forgetting and indifference, as particularly expressed in Histoire(s) du cinéma. Hence the extreme importance for him to find and exhibit, in one way or another, images that would attest to the event.

Didi-Huberman (2003) employs a quotation from Godard (1998) as an epigraph to his text: "even scratched to hell, a mere thirty-five millimetre 
rectangle saves the honour of the real" (p. 86) to describe the importance of the film stock Georges Stevens used to shoot the death camps in 1945.

Jacques Rancière (2005) proposes a critical vision that seems to me quite relevant to the Godardian approach:

[T] he filmmaker's position belongs to a properly iconic conception of cinema that Histoire(s) du cinéma illustrates at length. Cinema, Godard (1998) says, is not an art or a technique, it is a mystery. This "mystery" is nothing other than that of the incarnation. Cinema is not an art of fiction, the cinematographic image is not a copy, not a simulacrum. It is the imprint of truth, like the image of Christ on the linen of Veronica. The image is testimony of truth because it is the very mark of a presence. Since there were camps, there are pictures. The cinema was guilty of missing them, and those who wanted to proscribe the images of horror at the same time refused the testimony of those images. (pp. 71-72)

Lanzmann (1994), on the other hand, denounces the spectacular obscenity of the images attempting, in a totally illusory way, to visually represent what cannot be represented because "unimaginable". In his opinion, these visual archives do not allow the spectator to see anything, except a pure surface of informative visibility. In an interview, Lanzmann explained that he has always said that archival images are images without imagination: "They petrify thought and kill any possibility of evocation. It is much better to do what I did, an immense work of elaboration, creation of the memory of the event" (Bougnoux, 2001, p. 274). Against these images, which stupefy and prevent any reflexive progress, Lanzmann chooses the words of the witnesses:

What good is it to look at archival images by implicitly assigning them a greater probative value than testimonials? [...] The Holocaust was also this murder of speech, both by Nazi propaganda in the manipulation of the murdered, by lying in front of the gas chambers, -and in the effort to remove traces, evidence. To prefer the film archive to the words of the witnesses, as if this one proved more than these, it is, surreptitiously, to carry on this disqualification of human speech in its destination to the truth. (p. 274)

Against the use of the archival image, Lanzmann puts forward the figure of the Witness, a survivor from the Sonderkommando, whose speech 
is confronted with the question of the unsayable and, at the same time, acquires an absolute and a near-sacred value insofar as it expresses itself in the name of the dead, of the victims.

In another interview, Lanzmann (2009) explains:

Shoah is a film about the dead, not a film about the survivors. The dead were dead and the living were only there for them. That is why I call the Jewish protagonists of Shoah "revenants," because in reality none of them should have survived and, if they could, their survival was a miracle. I hold them to be heroes, saints and martyrs. They totally forget themselves and speak with total self-denial. They do not tell how they survived. They never say "I," they say "we." They are the spokesmen for the dead. (para. 14)

If I have dwelt on this controversy that I am tempted to sum up, in what is undoubtedly an over-simplified manner, as faith in the salvationary capacity of the Image on the one hand, and in Speech on the other, it is because it seems to me, following Jean-Michel Frodon (2004a) that the cinema of Rithy Panh both shifts and challenges this dichotomy through the place and use he reserves for the archive, and the visual archive in particular. In his article, Frodon does not really explain what the shift carried out by Rithy Panh consists of. He points out that "the production pulverizes the antiimage dogma like the abusive belief in the power of images" (p. 22) without developing the idea.

The opening of Bophana, A Cambodian Tragedy (1996), the first film Rithy Panh directly devoted to the memory of the crimes of the Khmer Rouge regime, shows a fundamental gesture that heralds the whole of his cinema. I'm referring to the gesture of the uncle who in S21 (the centre for torture and execution directed by Duch) passes in front of a series of anonymous photographs arranged side by side on a panel hung on the wall, and points to a photo of his niece Bophana whom he calls "Môm".

This gesture goes against the logic of the archives of the center S21, which are the product of the bureaucracy of mass death perpetrated in this centre, because this logic was aimed precisely at instantly dehumanizing the prisoners who entered the centre by depriving them of their names and classifying them anonymously. It also recreates a posthumous link, a memorial link, between uncle and niece whom the Khmer Rouge separated at the beginning of the regime, the uncle having always blamed himself for doing nothing to avoid this separation. It ultimately shows, in a very clear way, the process of Rithy Panh who refuses to deal with the Khmer Rouge genocide in the form of a generalized historical account, preferring instead 
to focus on the individual, concrete experiences of the victims on the one hand and the torturers on the other.

In the same way that the uncle's gesture restores his niece's name to the her photograph, Rithy Panh has recourse to the love letters Bophana sent her husband. She signed using the name "Seda" to reference the heroine of the epic poem "the Riemker" (the Khmer adaptation of the Ramayana). Rithy Panh finds the letters in Bophana's file at S21, where she was tortured and executed: the letters were consigned to the archives to serve as additional proof of the revolutionary truth-the treachery of Bophana and her husband that they admitted to in their respective confessions (obtained under torture, of course). Removing them from this radical archival ordering of human life that ultimately aims to replace the man (who is out of place in the new totalitarian society) by his confession, his file, Rithy Panh makes rhetorical use of these letters which are read over the regime's propaganda archives showing the collective work of women in the rice fields: the desperate affirmation of a lyrical subjectivity by the female voice violently subverts the collectivist propaganda that denies any form of individuality. This procedure of critical reading of the archives, through editing, allows one archive to interact with another rhetorically by revealing a gap, in this case between official propaganda and subjective experience (Niney, 2000).

Bophana (1996) heralds an essential approach in Panh's cinema that is completely different from the practice of rhetorical editing: the setting up of a space in the present, which brings together victims, torturers and archives. Nath, the painter who survived S21, meets Him Houy, a former security supervisor at the centre. Nath shows Houy his paintings and asks him if they are exaggerated and whether Houy can confirm that these representations are accurate. However it was S21 The Khmer Rouge Death Machine released in 2003 where his cinema affirms itself as a cinema of relationships that aims to create a common space in the present in which victims, perpetrators, and archives interact. This space, which is the concrete one of the former S21 centre, the central link in the Khmer Rouge regime's policy of mass destruction, has a political dimension from the outset. Gathered together in the same shot, without being systematically separated by shot/reverse shot configurations, perpetrators and victims are part of the same world, but their places are not interchangeable. The perpetrators cannot easily pretend (as indeed they attempt to at the beginning of the film) to also be victims whilst contemplating their actions at S21. When questioned by Nath, the painter already featured in Bophana who embodies a sort of double of the filmmaker, the former jailers give concrete details about what happened at S21 and what they did there. 
What role do the archives play in this space? Excluding audiovisual materials, archives are very varied in nature: lists of prisoners, instructions for the interrogators, confessions, photographs and paintings by Nath. Their presence triggers the speech of the perpetrators, some of whom stop being silent and abandon their complete denials. This is why I choose to name them interpellation-archives or "interpellators."

Prak Khan, a former interrogator at the centre, looks in a sequence at several photographs of tortured prisoners and, while precisely indicating the location of a place shown in the photo, details the method of torture employed. He goes on to explain how a prisoner might be patched up in order to continue the torture. Prak Khan and Him Houy, the guard already interrogated by Nath in Bophana, are also able to use a photo of a prisoner lying on the ground to find the exact spot where the man was located. Then they explain, by indicating the traces on his body, how the prisoner died under torture and was dragged into the corridor where the photograph was taken, before being buried behind the prison. There is a use of the visual archive, which goes against the logic of the Khmer Rouge archiving, since the photograph is used in the last example to trace concretely what happened to this man at the time of his death. The archive thus helps to give him back a form of singularity, instead of serving as an administrative document attesting to his elimination. In other sequences, the archives also put the perpetrators on the spot when it comes to their personal actions: Prak Khan, when confronted with a photograph of a young female prisoner, admits that he hit her all the more violently because he was attracted to her.

With this use of the archives inside the filmed space of S21, it could be said that Rithy Panh bypasses the contradiction described earlier between the belief in the salvationary virtue of the Image, and the Speech or the Witness on the other. Archives provoke the speech of the perpetrators who, in turn, confirm the images' validity, and their precise indexed relationship to reality. But images do not represent ultimate truth or definitive proof as if the image was the necessary instance that can alone truly attest to what took place. Images challenge the perpetrator and lead him out of silence and denial to begin speaking from his viewpoint about what happened, and to witness the event. In Rithy Panh's film, this fragile speech of the perpetrator engendered by the co-presence of the archive is at least as important as the archive itself.

This leads us to a fundamental, ethical question posed by the film to the spectator: if the archives confer on the perpetrators the status of "subjects of the gaze", could perpetrators attain, in the space of the film, the status of witness and become capable of distancing themselves, reflecting on 
their actions, and, in doing so, assume responsibility for their acts? Things are not so simple of course. The perpetrators' attitudes reveal how they underwent a moral process of "loss of humanity" from the moment they entered the Khmer Rouge death machine. A whole series of scenes in the film show former jailers and interrogators verbally describing and miming the daily gestures they made at S21: the routine of doing the rounds, checks, searches, blows, and even executions. Certainly, we can see at first glance in this a liberation of speech-as in the scenes already described including archives. But here, the bodies, themselves, insofar as they seem to mechanically repeat the gestures and work postures of torturers, do the work of archives in preserving the trace, the stamp of mass murder, founded on the dehumanization of prisoners and made possible by the torturer's loss of humanity.

This notion of the body-archive was put forward by Sylvie Rollet (2008): "By recording the gestures of the past, repeated and described without distance, the camera makes a 'body-archive' appear, which retains the mark of obedience and can reproduce it, but the repetition of which does not historicize the experience" (p. 11). This notion is particularly pertinent to a scene in which Khieu Ches, a former jailer, seems to literally relive a search scene and starts addressing the prisoners as if they were there, in a form of reenactment exhibiting traumatic memory as explained by Deidre Boyle (2009). The body-archive manifests the persistence of inhuman behaviour in the present, as if something of the death machine is revealed to us through the body-archive of the jailer (rather than to him). What is more, the halting, mechanical diction with which, during the film, the former torturers repeat revolutionary principles and instructions which were mostly aimed at withdrawing all humanity from the prisoners, suggests that these men still find it difficult to distance themselves from the revolutionary indoctrination of the past. On the other side of the archive-interpellation that arouses a conscious speech which begins to put the event into a story, Rithy Panh exhibits and makes audible the resistance of the body-archive, which is a trace, an enduring imprint in the present of indoctrination and of past humanity loss.

In this respect, I disagree with Leslie Barnes's (2016) analysis: "Panh's goal in the film appears to be to create a situation in which mutual recognition between the victim and the torturer, the enemy and the ally, and the past and the future might be possible" (p.195). If there is a common space created by the film, I do not believe that it is a question of mutual recognition. There is no symmetry of place or dialogue between interlocutors located at the same level. Barnes then finds failure in this operation: 
What is less clear is the extent to which this project is successful: the former guards are able to confront the evidence of their wrongdoing but they are unable to accept responsibility for their actions, much less to see these actions as criminal. As mere cogs in the killing machine, forced to obey orders or be killed, the guards claim no hatred or ideological motivation to explain their actions. Instead, they hide behind the Cambodian word used to describe what they did: kamtech, which means 'to eliminate'. Insisting that their task was to eliminate, rather than kill, the enemy, the guards allow themselves to continue denying the humanity of their victims. (pp. 195-196)

In my opinion, this negative observation shared by Hamilton (2013) concerning the possibility of a reflexive journey of the perpetrators must be qualified. Prak Khan, the interrogator mentioned earlier, seems to enter a chain of personal reflection when he evokes in a sequence the loss of moral control of his actions: "when you torture, you have a cruel and savage heart. I didn't think about it...When I raised my hand, my heart didn't prevent my hand or my foot from striking" (Pahn, 2003).

Him Houy, too, seems in another sequence to understand the gravity of his acts when he evokes his own shame. In any event, it seems to me that the film (in the work it accomplishes with the victims and the torturers present in the common space created by it) does not pretend to answer the question posed earlier concerning the possibility and degree of dawning awareness. The question remains open to the assessment of each viewer, but insofar as it is posed, it opens the possibility of a common space nevertheless, without seeking forgiveness. We thus see how the bypassing of the Image/Witness split is accompanied by a double shift: first, as Sylvie Rollet (2008) points out, it is also the torturers, not just the victims, who must confront the memory of the catastrophe; secondly, given how perpetrators and victims of the Khmer rouge regime are still living side by side in today's Cambodian society, the political question of the relationship of the present with the past becomes essential.

The common political space of the present filmed by Rithy Panh is also a spectral space: this questioning of the perpetrators, solicited both by Nath and the archives, takes place under the gaze of victims killed at S21, and Bophana in particular. We thus repeatedly see her photograph in the filmed space without her being directly linked to the speech of the guards. Having always signed her multiple confessions under torture using the name "of Seda Deth" ("Deth" was her husband's first name), she embodies the spirit of resistance par excellence against the process of dehumanization. In 
this sense, she represents, in the space of the present, a spectral presence and observer who watches over the proceedings on behalf of the victims. Furthermore, this space is also often shown as an empty space that opens onto what it doesn't make visible, its internal "off camera" so to speak, in other words the death of thousands of victims. It is particularly striking in the scenes already mentioned involving the body-archives of the torturers. Finally, it is necessary to cite the use of an archive that responds both to the function of the questioning of the torturers, and the spectral function.

It concerns an immense photograph, rolled out on the floor, which represents the charnel house of Choeung Ek where the S21 prisoners were executed. Houy explains in detail how this took place: from the transportation by truck from S21 up to the moment of execution. At one point, he indicates with his finger the location of a long-gone building where the prisoners were confined before execution. The simple line in the dust, associated with the passing of time and memory, thus comes to embody the "house of death" (Frodon, 2004b, p. 15) and takes on a spectral dimension. Thus, on the other side of the body-archive of the perpetrator, Rithy Panh reveals in the spectral archive the presence of those who are definitely absent, the ghostly presence of the deceased victims, represented first by the emblematic figure of Bophana-Seda. This concept of ghostly presence must certainly be understood in its full cultural meaning: there are indeed in the traditional Khmer culture. Strong beliefs, which are still very much alive today, even in urban areas, in "wandering souls" who, if their bodies could not be cremated, are condemned to wander without respite.

From this point on, it can be argued that another change, this time in relation to the role assigned to the Witness, takes place in Rithy Panh's cinema when related to the confrontation Image/Speech. As I have already noted, Claude Lanzmann (2009) explains that the Jewish witnesses who are "miraculous" survivors of the Sonderkommandos speak only on behalf of the dead without talking about themselves. As spokespersons for the dead, their words acquire a very strong symbolic value, in an almost sacred form, insofar as they ceaselessly refer to the death of those who can no longer testify. In the cinema of Rithy Panh-in Bophana and especially in S21-the painter Nath, one of the very few survivors of S21, is the essential witnesssurvivor-"revenant" (to use Claude Lanzmann's expression), but he testifies as much through his paintings, a form of visual archive, as through his words. Moreover, next to the figure of the witness, Nath, appears another figure, that of Bophana-Seda, the spectral archival observer, who, in so far as it corresponds to a culturally specific vision to envisage death, embodies the absence-presence of deceased victim. From a Cambodian cultural perspective, this figure may be called a "revenant." 
Finally, I wish to examine the way in which in his later film, Duch, Master of the Forges of Hell (released in France in January 2011), Rithy Panh re-uses (or not) the archives with the functions displayed in 521 : the interpellationarchive, the body-archive and the spectral archive. Comparison with $S 21$ is inevitable in the sense that these two films appear to be a diptych concerning the Khmer Rouge death machine.

Kaing Guek Eav, alias Duch, the former director of the center S21 during the Khmer Rouge regime, is effectively the figure of power and absent authority. He does not directly appear in $S 21$, but is constantly present in the archives (photographs, written records, signatures) and in the discourse of jailers and interrogators.

Rithy Panh filmed the former director in 2009 before the opening of his trial by the Extraordinary Chambers in the Courts of Cambodia (ECCC), the mixed tribunal, both national and international, charged with judging the crimes of the Khmer Rouge leaders. Rithy Panh therefore filmed Duch alone using an apparently very simple setup: an interview to camera without the shared space found in the film S21. From Duch's head movements and oblique glances, viewers sense the presence of an off-camera interlocutorRithy Panh himself_-although Panh doesn't explicitly intervene in the film.

Three hundred hours of filming Duch plunged Rithy Panh into a deep interior crisis that led him to recount the experience with Christophe Bataille in a co-authored book titled The Elimination (2011), and then to direct the film The Missing Picture (2013), in which he evokes his traumatic personal memory of the Khmer Rouge catastrophe.

In Duch (2012), it is therefore a confrontation between what is on and off camera, between Duch and Rithy Panh, but also between Duch and the viewer who is confronted with the former director of S21 in a direct visual relationship. In the foreground of the screen, on the desk behind which Duch sits, there are varied visual archives-party slogans, photographs, confessions, lists of prisoners, etc.- - which concretely surround him, and the solicitations to which he will have to reply. It is therefore the same type of approach as in the film $S 21$, using mostly photographic archives. It is a case of confronting Duch as much as possible with the same archives as the actors of $S 21$, in a form of investigation which continues from one film to another, intercutting the various discourses. But the result of these solicitations is very different in the film Duch, Master of the Forges of Hell. Instead of sticking to factual developments in the form of micro-stories, like the jailers and interrogators in the film $S 21$ (2003), Duch, as master of the revolutionary speech, or at least believing himself to be so, tries to use the archives which are presented to him to justify himself and present himself in a favourable light. For example, he brandishes a photograph of a 
cell with a boy in the foreground, whose gaze implies great gentleness and goes on to describe the photo as terrifying in order to justify his assertion that he never visited the cells and interrogation rooms and preferred to know nothing concrete about what was happening. The archives therefore become the object of a battle, with Rithy Panh's editing responding to Duch's revolutionary casuistry to reveal his contradictions and lies from a distance. Later in the film, Duch reads a confession in which the accused requests, in a supplicatory way, that Duch return to see him, and Duch must therefore acknowledge his presence. His respect for the archive-which contains the revolutionary truth in the name of which the prisoners are "crushed"-is thus turned against him and Rithy Panh simply exposes the truth. Elsewhere however, when Duch explains that his assistant, Man, was an excellent interrogator who only used torture in a moderate way, Rithy Panh confronts him with unedited rushes from $S 21$, including testimony by a former jailer who mentions an execution carried out by Man, but Duch vigorously denies this by claiming that it's "one word against another".

Faced with the crafty discourse of the former director of S21 who clouds the issue by admitting certain things in order to lend more credibility to his subsequent denials, acknowledging that he is the agent of the crime at S21, but quickly adding that he is also a hostage of the regime, Rithy Panh also resorts to external audiovisual archives with regard to Duch's statements. His use of them is undoubtedly more varied than in Bophana (1996) in which he confronted one archive with another. Here, he uses archives to comment ironically on Duch's statements: when Duch mentions a discourse by Mao that impressed him, Rithy Panh shows a young revolutionary on a platform reciting revolutionary slogans accompanied by big gestures. Thus, Duch's ideological conversion takes the form of mere indoctrination.

Furthermore, the archive completes Duch's idea to expand the meaning: in a rare moment when Duch seems capable of distancing himself from Khmer Rouge ideology, by stating that he betrayed his ideals as a teacher by turning the Tuol Sleng high school into a place of torture, Rithy Panh cuts the confession with an image of children carrying loads in the rice field.

The archive can also reveal the extreme violence and the process of dehumanization which lies behind Duch's explanations: when he speaks, with a neutral tone about fatal blood sampling and the medical experiments carried out in S21, and partially justifies it all as the result of the necessities of the war and the advantage of destroying the inmates at S21 rather than taking them to Choeung Aek, the archives produced by the Khmer Rouge of medical tests on animals symbolically show the regime's attitude towards the prisoners. 
Duch is also sometimes trapped by his enjoyment of speaking and his desire to show the extent of the power he held at the time. He thus starts to explain how he dealt with the training of his subordinates, and then talks increasingly loudly when saying that one must not hesitate to strike the enemy, and then ends up switching to second-person as if his subordinates were present off-camera. Here, again, is the phenomenon of the body-archive that was present in the film S21 (Pahn, 2003), and it is all the more disturbing that Duch says at that instant that he embodies the Party, thus showing the extent to which he remains mentally formatted by Khmer Rouge ideology.

While Rithy Panh's approach in Duch, Master of the Forges of Hell (2012) remains an open one that offers Duch a free space of expression, it is noticeable that, far from representing, as in $S 21$ (2003), a shared space in which some perpetrators try to make a path towards the recognition of the truth, the film becomes the site of a silent struggle between Duch and the filmmaker who uses the means of cinema-the archives submitted to Duch on camera, the interpellation-archives, and the audiovisual ones edited in counterpoint to Duch's words - and of editing to undo the denial strategies of the former director of S21. In this silent struggle, the figure of Bophanathe emblematic spectral observer who passes through the film, as she did in S21-is present on Duch's desk and in the interstices of the editing and wins an ultimate victory: not only is Duch forced to admit, when faced with his own annotations of Bophana's confessions, that he had closely followed her interrogations and those of her husband (having at first pretended that he didn't remember the photographs of Bophana), but he calls Bophana "Seda," by the name with which she signed her confessions - a name borrowed from the heroine of the Riemker precisely to express her love for Deth. Incapable of understanding this ultimate act of resistance by Bophana, who even under torture finds the means to express her irreducible singularity, Duch, the master of the forges of Hell, is finally and definitively vanquished. 


\section{References}

Barnes, L. (2016). 'The Image of a Quest': the Visual Archives of Rithy Panh. Australian Humanities Review, $59,190-208$.

Bougnoux, D. (2001). Le monument contre l'archive ? Entretien avec Claude Lanzmann [The monument against the archive? Interview with Claude Lanzman]. Les Cahiers de médiologie, 11, 271-279.

Boyle, D. (2009). Shattering silence:Traumatic memory and reenactment in Rithy Panh's S-21, The Khmer Rouge killing machine. Framework, 50(1), 95-106.

Didi-Huberman, G. (2001). Images malgré tout [Images in spite of all]. In Clément Chéroux (Ed), Mémoire des camps. Photographies des camps de concentration et d'extermination Nazis [Memory of the camps. Photographs of Nazi concentration and extermination camps], 1933-1999 (pp. 219-242). Paris: Marval.

Didi-Huberman, G. (2003). Images malgré tout [Images in spite of all]. Paris: Les Editions de Minuit.

Frodon, J-M. (2004a). Juste des images [Just images]. Les Cahiers du Cinéma, 587, 19-22.

Frodon, J-M (2004b). La maison des morts [The house of the dead]. Les Cahiers du Cinéma, 587, 15.

Godard, J-L. (1998). Histoire(s) du cinéma [History(ies) of cinema]. Paris: Gallimard-Gaumont.

Hamilton, A. (2013). Ethics and aesthetics in the cinema of Rithy Panh. In Bangert. A., Gordon R. S. C. \& Saxton L. (Eds.), Holocaust intersections: Genocide and visual culture in the new millenium (pp. 170190). Oxford: Legenda.

Lanzmann, C. (1994, March 3). Holocauste, la représentation impossible. [Holocaust, impossible representation] Le Monde, p. 23.

Lanzmann, C. (2009). Je refuse de comprendre [I refuse to understand]. L'obs, March 5. Retrieved from http://bibliobs.nouvelobs.com/essais/20090305.BIB3088/claude-lanzmann-je-refuse-decomprendre.html

Niney, F. (2000). Les archives [The archives]. In L'épreuve du réel à l'écran : essai sur le principe de réalité documentaire documentaire [The test of reality on screen: Essay on the principle of documentary reality] (pp. 253-292). Brussels: De Boeck University.

Pahn, R. (Director). (1996). Bophana: a Cambodian Tragedy. France: Catherine Dussart Production.

Pahn, R. (Director). (2003). S21: The Khmer Rouge Death Machine. France: Institut National de I'Audiovisuel and Arte France Cinema.

Pahn, R. (Director). (2012). Duch, Master of the Forges of Hell. France: Catherine Dussart Production and Cambodia: Bophana Productions.

Panh. R \& Bataille, C. (2013). The elimination: A survivor of the Khmer Rouge confronts his past and the commandant of the killing fields. (J.Cullen, Trans.) New York, NY: Other Press. (Original work published 2011.)

Rancière, J (2005). Chroniques des temps consensuels [Chronicle about a consensual period]. Paris: Seuil, Collection Librairie du XXle siècle.

Rollet, S. (2008). L'art témoin de S21 :à l'épreuve de la catastrophe génocidaire, construire une mémoire partagée? [The art witness of S21. Building a shared memory in the face of the genocidal catastrophe?]. Intermédialités, [electronic edition], "Accompagner (au cinéma)", n³, 1-14. Retrieved from http://cri.histart.umontreal.ca/cri/fr/intermedialites/accompagner/pdfs/e_rollet_3.pdf

Wacjman, G. (2001). De la croyance photographique [About the belief in images]. Les Temps Modernes, 613,46-83. 


\section{Notes}

1 This and all subsequent translations from the French are by the author, except where otherwise noted.

ERIC GALMARD worked in several Asian countries (the Philippines, Cambodia and Japan) and in the Pacific region (Fiji Islands), both in university and in the French cultural network. Since 2009 he has taught films in the Faculty of Arts at Strasbourg University, notably lecturing in documentary cinema and Asian cinemas. He has also made recently a documentary feature-length film, A Tomb for Khun Srun (corresponding author: Email adress : galmard@unistra.fr). 